\title{
Atatürk Döneminde Türk Uzmanların Yabancı Ülkelerin Eğitim Sistemleri Hakkında Hazırladıkları Raporlar ${ }^{*}$
}

\section{Cengiz Aslan ${ }^{* *}$}

Öz

Türk eğitim tarihinde yabancı uzmanların Türkiye'yle ilgili hazırladıkları raporlar kadar önemli olan diğer bir dokümanter kaynak da dönemin Türk uzmanlarının yabancı ülkelerin eğitim sistemleriyle ilgili hazırladıkları raporlardır. Atatürk döneminde çeşitli ülkelerin eğitim sistemlerini incelemek üzere yurt dışına çok sayıda uzman gönderilmiştir. Onların hazırladıkları raporlar, Türk eğitim sisteminin düzenlenmesinde ve alınan kararlarda oldukça etkili olmuştur. Bu çalışmada ulaşılan belge ve bilgiler çerçevesinde, Atatürk döneminde çeşitli ülkelerin eğitim sistemlerini incelemek üzere yurt dışına gönderilen uzmanlar belirlenmeye çalışılıış ve onların çeşitli ülkelerin eğitim sistemlerine yönelik hazırladıkları raporlar incelenmiştir. Bu çerçevede öncelikli olarak Almanya, Fransa, Avusturya, Bulgaristan ve Rusya eğitim sistemleri hakkında yayımlanmış olanlar değerlendirilmiştir.

\section{Anahtar kelimeler}

Türk uzmanlar, raporlar, Almanya, Fransa, Avusturya, Bulgaristan, Rusya.

"Geliş Tarihi: 27 Nisan 2016 - Kabul Tarihi: 18 Aralık 2019

Bu makaleyi şu şekilde kaynak gösterebilirsiniz:

Aslan, Cengiz (2021). "Atatürk Döneminde Türk Uzmanların Yabancı Ülkelerin Eğitim Sistemleri

Hakkında Hazırladıkları Raporlar”. bilig - Türk Dünyası Sosyal Bilimler Dergisi 96: 283-310.

" Dr., Ankara Üniversitesi, Eğitim Bilimleri Fakültesi, Eğitim Bilimleri Bölümü - Ankara/Türkiye

ORCID ID: 0000-0003-3710-9838

cngzaslan@gmail.com 


\section{Giriş}

Osmanlı Devleti’nde oluşmaya başlayan, Atatürk döneminde gelişmiş ülkeler model alınarak sürdürülen modernleşme düşüncesi, çağdaş bir toplum olmanın koşullarını hazırlamaya katkıda bulunmuştur. Bu düşüncenin ilk adımı, eğitim sisteminin bu çerçevede düzenlenmesidir. Ancak, Cumhuriyet'in ilk yıllarındaki çoğu ebeveynin, İsmail Hakkı'ya göre çocuklarının eğitimini üstlenebilecek olanakları yoktu. Ulusun çoğunluğunu oluşturan bu durumdaki vatandaşların eğitimi, onların üretken bir duruma getirilmesi, devletin en önemli görevleri arasında kabul edilmiştir (İsmail Hakkı 1925: 46). Hasan Âli Yücel (1941: 2)'e göre Cumhuriyet'in en önemli davalarından biri, Türk Milleti'nin, özellikle XIX. yüzyılda bilimde, teknikte, endüstri ve ekonomide dev adımlarla büyük hamleler yapmış olan Batı medeniyetine, onun doğal bir parçası olarak dâhil olmasıydı. Kuşkusuz Atatürk devrimleri ile imparatorluktan ulus devlete geçiş sürecinde yeni insanı yaratmanın koşulları, milli güzideleri yetiştir$m e^{1}$, muasır medeniyetlerin deneyim ve birikimlerinden yararlanılmasıyla gerçekleşebilecekti. Bu sürecin en etkili yolları arasında yurt dışına öğrenci gönderilmesi, yurt dişından uzmanlar çağrılması, yurt dışına araştırma ve inceleme için uzmanlar gönderilmesi ve tercüme faaliyetleri gösterilebilir.

Atatürk döneminde birçok alandan öğretmen, müfettiş ve bürokrat hem bilgi-görgü artırmak hem eğitim derecesini yükseltmek hem de eğitim sistemine yönelik inceleme ve araştırmada bulunmak için yurt dışına gönderilmiştir. Ayrıca yurt dışında yapılan önemli sempozyum, kongre gibi uluslararası bilimsel toplantıları yakından takip etmenin yanı sıra sergi, kutlama gibi ülkelere özgü önemli günlere katılıma da özen gösterilmiştir (Aslan 2014: 62). Bu süreçteki temel etkenin Cumhuriyet'in dünya gündemini ve yenilikleri izleme, kendisi için gerekli olanı alma ve yararlanma, kendisini yeniden düzenleme isteğinin ve felsefesinin olduğu söylenebilir. Diğer bir deyişle yeni kurulan Cumhuriyet'in Batı medeniyetindeki gelişmeleri gözeten bir modernite projesi bulunmaktadır. Bu çerçevede, ülkenin farklı kentlerinden eğitim yöneticisi, öğretmen ve akademisyenlerin yurt dışında yapılan çeşitli bilimsel toplantılarda etkin olarak rol aldıkları, bildiriler, raporlar sundukları, yurt dışında yaptıkları inceleme ve araştırmalarını raporlaştırdıkları ve bu raporları Bakanlığa sundukları anla- 
şılmaktadır. Bu raporlardan bazılarının dönemin dergi ve gazetelerinde, bazılarının ise genişletilerek kitap olarak yayımlandıkları görülmektedir. Bu çalışmada incelenemeyen, ayrı bir çalışmada ele alınması gereken yurt dışında görevli elçi ve öğrenci müfettişlerinin eğitimle ilgili hazırladıkları çeşitli raporlar da dönemin dergi ve gazetelerinde yer almaktadır. Bunların yanı sıra, Cumhuriyet' in eğitim sorunlarına ve çeşitli ülkelerin eğitim işlerine dair yazarı belli olmayan kitap, çeviri ve raporlar da bulunmaktadır.

Türkiye'den 1923-1940 yılları arasında en çok öğrenci gönderilen ülkeler sırasıyla Almanya, Fransa, Belçika, İsviçre, Amerika, İngiltere, İtalya, Avusturya, Çekoslovakya, Macaristan, İsveç ve Rusyádır (Aslan 2014: 216). Bununla birlikte, çeşitli ülkelerin eğitim işlerine dair hazırlanan rapor sayılarına bakıldığında Almanya, Rusya, Fransa, Bulgaristan ve dönemin eğitim alanında Mektepçiliğin Kâbesi² olarak kabul edilen Avusturya öne çıkmaktadır.

Bu çalışmada, ulaşılan belge ve bilgiler çerçevesinde Atatürk döneminde çeşitli ülkelerin eğitim sistemlerini incelemek üzere yurt dişına gönderilen uzmanlar belirlenmeye çalışılmıştır. Bu çerçevede, yurt dişına gönderilen Türk uzmanların inceledikleri ülkelerin eğitim sistemleri hakkında hazırladıkları raporlar ve kitaplar ele alınmıştır.

$\mathrm{Bu}$ araştırma nitel bir araştırmadır. Araştırmanın yöntemi, nitel araştırma yöntemlerinden biri olan tarihsel araştırmadır. Tarihsel araştırmalar, geçmiş bir zamanda ol(uş)muş eylem ya da olayların anlaşılması için tanımlama ve açıklama amacına yönelik sistematik biçimde veri toplama ve değerlendirme çabası olarak tanımlanabilir (Fraenkel vd. 2012: 535-537). Araştırmanın veri kaynaklarını Almanya, Fransa, Avusturya, Bulgaristan ve Rusya’nın eğitim sistemleri hakkında yayımlanmış olan rapor ve kitaplar oluşturmaktadır. Çalışma kapsamında yer alan dokümanlar, betimsel analiz yaklaşımına göre incelenmiştir.

\section{İnceleme ve Araştırma İçin Yurt Dışına Gönderilen Uzmanlar}

Gelişmiş ülkelerin eğitim düşüncesini, kurum ve kuruluşlarını incelemenin en etkili yollarından biri, o ülkelere uzman gönderilmesidir. Bu incelemelerin gerekliliği, hazırlanan çeşitli raporlarda da yer almıştır. Örneğin, 
1924 yilında Türkiye'ye davet edilen John Dewey'in raporunda, özel bir inceleme komisyonu kurulması ve bu komisyonun bir yandan yabancı ülkelerdeki okul binalarını, bahçeleri, oyun yerlerini incelerken diğer yandan çeşitli yaşamsal, toplumsal ve çevresel şartlar arasındaki ilişkileri incelemesi gerektiği (Dewey 1939: 2) belirtilmektedir. Benzer biçimde dönemin eğitimcilerinden Sadrettin Celal (Antel) de, çeşitli ülkelerde maarif teşkilatları ve eğitim uygulamaları hakkında inceleme ve araştırma için bir heyet kurulması gerektiği (Maarif Vekâleti Mecmuası 1926: 237) önerisinde bulunarak konunun önemi ve gerekliğini vurgulamıştır.

Ulaşılan belge ve kayıtlar çerçevesinde, Bakanlık Müfettişi Ahmet Hilmi (Yolaç) 1925 yılında Bulgaristan'da, aynı yıl Adana Öğretmen Okulu öğretmeni İsmail Hakkı (Tonguç) Avrupa ülkelerinde, 1925-1926 yıllarında tedavi amaciyla Avusturya Viyana'da bulunan İstanbul Erkek Öğretmen Okulu pedagoji öğretmeni Hıfzırrahman Raşit (Öymen) Viyana’da (Altunya 2015: 288-300), Bakanlık Müsteşarı Nafi Atuf (Kansu) ile Teftiş Kurulu Başkanı Rıdvan Nafiz (Edgüer), 1926 yılında Ukrayna ve Rusya’da (Kansu vd. 2011: 66) incelemelerde bulunmuşlardır. Maarif Vekili Mustafa Necati, Talim ve Terbiye Heyeti Reisi, Darülfünun Felsefe Tarihi Müderrisi Mehmet Emin (Erişirgil) ve Sanayi-i Nefise Şubesi Müdürü ve Maarif Genel Sekreteri Namık İsmail'den oluşan heyet, ülkemizde yeni yapılacak eğitim ve kültür hareketlerinde, örnek alınabilecek teşkilat ve kurumları tanımak üzere Avrupa ülkelerine (Çekoslovakya, Almanya, Fransa, İngiltere ve İtalya) iki ay süren bir inceleme seyahatine çıkmışlardır (Maarif Vekâleti Mecmuası 1927: 121). Mustafa Necati'nin 1927 yılında yaptığı bu yurt dışı seyahatinden sonra yurt dışı eğitimi ve incelemelerinde ve bu ülkelere öğrenci gönderilmesinde bir yoğunluk olduğu söylenebilir.

1929 tarihli Talim ve Terbiye Heyeti (TTH) kararına göre, Heyet üyelerinden Ali Haydar (Taner) Bulgaristan’a; Vekâlet müfettişlerinden Hasan Âli (Yücel) Fransa'ya; Reşat Şemsettin (Sirer) Almanya'ya; Tevfik Bey İsviçre’ye; Vekâlet müfettişlerinden Kadri (Yörükoğlu) Avrupa’ya; 1929/1930 yılında Jena Üniversitesi'nde açılacak kurslara devam etmek ve Alman okulları hakkında incelemede bulunmak isteyen Balıkesir Erkek Öğretmen Okulu Terbiye ve Usulü Tedris öğretmeni Fuat (Gündüzalp) 
Jena’ya (TTH kararı 1929; Gündüzalp 2010:17); 1931 yılında Vedide Baha (Pars) Fransa ve İsviçre'ye (Gündüzalp 1961: 108); 1931 yılında, İstanbul Kız Öğretmen Okulu Tabii İlimler öğretmeni Dr. Sabri, Avrupa'ya (TTH kararı 1931); 1933 yılında, Vekâlet başmüfettişlerinden Ragıp Nurettin (Ege), Maarif teşkilat ve müesseseleri ile halk eğitimi hakkında incelemelerde bulunmak üzere ABD’ye; 1933 yılında, Erzurum Lisesi Felsefe öğretmeni Necati Avrupàya; 1933 yılında, Manisa Maarif Müdürü Hilmi mesleki incelemelerde bulunmak üzere Viyanàya (TTH kararı 1933); 1934 yılında, Üniversite Fen Fakültesi ahlak doçentlerinden Ziyaeddin Fahri (Fındıkoğlu) Strasbourg'a (TTH kararı 1934); 29 Ağustos-20 Eylül 1936 tarihlerinde, Sovyet Rusya Maarif Komiserliği tarafından davet edilen bir heyet Sovyet Rusyàya; 1937 yılında Mesleki ve Teknik Öğretim Genel Müdürü Rüştü Uzel genel ve mesleki eğitim konularında incelemelerde bulunmak üzere İtalyàya (Özalp vd. 1977: 783); 1937-1938 ders yılının yaz tatilinde İsmail Hakkı Tonguç Balkan ülkelerine gönderilmişlerdir (Tonguç 1939: 193). Ayrıca öğrenim için yurt dışına gönderilip bir yandan öğrenimlerini sürdürürken diğer yandan o ülke eğitim sistemine ilişkin rapor hazırlayanlar da bulunmaktadır. Örneğin; Ahmet Fuat (Baymur) 1928-1931 yılları arasında Viyana Yüksek Pedagoji Enstitüsü’ne; Gazi Öğretmen Okulu edebiyat öğretmeni B. O. Tahsin (Banguoğlu), mesleki bilgisini artırmak ve Avrupa'da incelemelerde bulunmak üzere 1931-1932 ders yılı sonundan itibaren bir yıllığına Almanya’ya gönderilmişlerdir (TTH kararı 1932). Bu durumda olan Vekâlet müfettişlerinden Yahya Tevfik Bey de 1934 yılında, Almanya’nın bilim ve kültür müesseselerinde incelemelerde bulunmak üzere bir yıllığına gönderilmiştir (TTH kararı 1934).

\section{Raporları Hazırlayanların Üstlendikleri Görevler}

Atatürk döneminde çalışma kapsamındaki raporları hazırlayanlardan Ahmet Hilmi Yolaç, Ali Haydar Taner, Hasan Âli Yücel, Ahmet Fuat Baymur, Hıfzırrahman Raşit Öymen, İsmail Hakkı Tonguç, Nafi Atuf Kansu, Reşat Şemsettin Sirer ve Rıdvan Nafiz Edgüer tablo 1'de görüldüğü üzere, Cumhuriyet döneminde öğretmenlikten, Bakanlık merkez teşkilatında üst düzey görevlere kadar çeşitli görevlerde bulunmuşlardır. Bu eğitimciler ayrıca eğitimle ilgili çeşitli toplantı ve komisyonlarda da görev almışlardır. 
Tablo 1. Raporları Hazırlayanlarn Üstlendikleri Görevler

\begin{tabular}{|c|c|c|}
\hline Raporu hazırlayanlar & Görevleri & Tarih \\
\hline \multirow[t]{5}{*}{ Ahmet Hilmi Yolaç } & Hars Dairesi Müdürlüğü & $1920-1921$ \\
\hline & Milli Eğitim Müdürlüğü & $1921-1923$ \\
\hline & Bakanlık Müfettişliği & $1923-1931$ \\
\hline & Başmüfettişlik & 1931-1949 \\
\hline & Gazi Eğitim Enstitüsü (GEE) Müdürlüğü & $1928-1929$ \\
\hline \multirow[t]{4}{*}{ Ali Haydar Taner } & Darülfünun Müderrisliği & 1919 \\
\hline & Türk Talebesi Teftiş Heyeti Başkanlığı & $1915-1918$ \\
\hline & Öğretmenlik & $1939-1948$ \\
\hline & Talim ve Terbiye Kurulu Üyeliği & $1926-1938$ \\
\hline \multirow[t]{9}{*}{ Hasan Âli Yücel } & Öğretmenlik & $1921-1927$ \\
\hline & Orta Öğretim Genel Müdür Yardımcılığı & 1925 \\
\hline & Bakanlık Müfettişliği & 1927 \\
\hline & GEE Müdürlüğü & $1932-1933$ \\
\hline & Orta Öğretim Genel Müdürlüğü & 1933 \\
\hline & Türk Dil Kurumu Başkanlığı & 1932 \\
\hline & Türk Dil Kurumu Üyeliği & $1942-1960$ \\
\hline & Maarif Vekilliği & $1938-1946$ \\
\hline & Türk Tarih Kurumu Üyeliği & $1940-1962$ \\
\hline \multirow[t]{7}{*}{ Ahmet Fuat Baymur } & Öğretmenlik & $1921-1928$ \\
\hline & İlk Tedrisat Müfettişliği & 1928 \\
\hline & GEE”de Öğretmenlik & $1933-1952$ \\
\hline & İlk Tedrisat Şube Müdürü & $1934-1943$ \\
\hline & GEE Müdürlüğü & $1950-1952$ \\
\hline & Talim ve Terbiye Kurulu Üyeliği & $1952-1960$ \\
\hline & İlköğretim Genel Müdürü & $1960-1961$ \\
\hline \multirow[t]{8}{*}{ H. Raşit Öymen } & Öğretmenlik & $1921-1922$ \\
\hline & GEE'de Öğretmenlik & 1934 \\
\hline & İstanbul İl Milli Eğitim Müdür Yard. & $1926-1934$ \\
\hline & Bakanlık İlköğretim Şube Müdürlüğü & 1936 \\
\hline & Milletvekilliği & $1943-1950$ \\
\hline & Okullar Müzesi Müdürlüğü & 1946 \\
\hline & Ankara Üniversitesi İlahiyat Fakültesi & 1960 \\
\hline & DTCF'de Öğretim Üyeliği & $1964-1966$ \\
\hline \multirow[t]{2}{*}{ İsmail Hakkı Tonguç } & Öğretmenlik & $1920-1935$ \\
\hline & GEE'de Öğretmenlik & 1929 \\
\hline
\end{tabular}


GEE'de Resim-İş Bölümü Şefliği ve Enstitü

Müdürlüğ̈̈

$1934-1935$

Mektep Müzesi Müdürlüğü

$1926-1935$

İlköğretim Genel Müdürlüğü

$1935-1946$

Talim ve Terbiye Kurulu Üyeliği

1946-1949

\begin{tabular}{lll}
\hline Nafi Atuf Kansu & Ankara Lisesi Müdürlüğü & 1921 \\
& Orta Tedrisat Umum Müdürlüğü & $1922-1924$ \\
& Maarif Vekâleti Müsteşarlığı & $1924-1927$ \\
& Türk Maarif Cemiyeti Başkanlığı & $1928-1935$ \\
& Halkevi Reisi & 1933 \\
& Milletvekilliği & $1927-1949$ \\
& Siyasi Müsteşarlık & 1937 \\
\hline Reşat Şemsettin Sirer & Öğretmenlik & 1923 \\
& Avrupa Talebe Müfettişi & 1926 \\
& Başmüfettiş & 1928 \\
& İlk Tedrisat Umum Müdürlüğü & 1933 \\
& Talim ve Terbiye Kurulu Üyeliği & $1939-1941$ \\
& Yüksek Tedrisat Umum Müdürlü̆̈̈ü & 1941 \\
& Milletvekilliği & $1943-1950$ \\
& Maarif Vekilliği & $1946-1948$ \\
\hline Rıdvan Nafiz Edgüer & Öğretmenlik & 1914 \\
& Okul Müdürlüğü & $1920-1925$ \\
& Teftiş Kurulu Başkanlı̆̆ı & $1924-1926$ \\
& Talim ve Terbiye Kurulu Üyeliği & $1926-1931$ \\
& Maarif Vekâleti Müsteşarlığı & $1933-1939$ \\
& Milletvekilliği & $1939-1948$ \\
\hline
\end{tabular}

Kaynak: Akyüz 1987:388, Altunya 2006:122-124, Aslan 2014:37-44, Gündüzalp 1955:287, Gündüzalp 1984:308, Gündüzalp 2010:165-273, Kansu vd. 2011:59-93, Kaya 1987:20, Kurtça 1987:125-128, MEB 1977:42, Oğuzkan 1987:611, Özalp vd.1977: 775-831, Sorguç 1987:452, Sorguç 1982:88, Tonguç 2009:39-515.

\section{Çeşitli Ülkelerin Eğitim Sistemleri Hakkındaki İncelemeler}

Dönemin Türk eğitimcilerinin çeşitli ülkelerin eğitim işlerine dair hazırladıkları rapor ve makaleler Maarif Vekâleti Mecmuası (MVM) başta olmak üzere Terbiye, Muallimler Mecmuası (MM), Muallimler Birliği, Fikirler, Hayat, Kültür, Ülkü, Yeni Türk, Yeni Fikir, Yeni Adam, Meslek, Süs, Resimli Şark, Gündüz Sanat ve Fikir, Enerji, İktisat ve Ticaret dergilerinde yayımlanmışıır. 
Ayrıca kitap olarak yayımlanan incelemeler de bulunmaktadır. Yazarı belli olmayan incelemeler tablo 2'de gösterilmemiştir. Bu tabloda, Türk eğitimcilerin yazdıkları rapor, tetkik, makale ve kitaplardan tespit edilen, yazarı belli olan ve yayımlananlar yer almaktadır.

Tablo 2. Çeşitli Ülke Eğitim Sistemleri Hakkındaki İncelemeler (rapor, tetkik, makale, kitap)

\begin{tabular}{|c|c|c|c|}
\hline Yil & Başlık & Yazar / Hazırlayan & $\begin{array}{c}\text { Yayımlandı̆̆ } 1 \\
\text { yer }\end{array}$ \\
\hline 1922 & Maarif İstatistikleri: Bulgaristan & Ali Haydar (Taner) & $\begin{array}{l}\text { Muallimler } \\
\text { Mec. (MM) }\end{array}$ \\
\hline 1922 & $\begin{array}{l}\text { Maarif İstatistikleri - İsviçre ve Balkan } \\
\text { Hükümetleri }\end{array}$ & Ali Haydar (Taner) & MM \\
\hline 1922 & Maarif İstatistikleri - Almanya & Ali Haydar (Taner) & MM \\
\hline 1923 & $\begin{array}{l}\text { Çekoslovakya İntibaları - Çekoslovakya } \\
\text { Cumhuriyeti Mekâtip ve Hars-1 Milli } \\
\text { Nezareti Teşkilatı }\end{array}$ & Ali Haydar (Taner) & MM \\
\hline 1923 & $\begin{array}{l}\text { Çekoslovakya İntibaları - Tali Muallimler } \\
\text { (Ortaöğretim) - Tali Muallimlerin Ünvan- } \\
\text { ları }\end{array}$ & Ali Haydar (Taner) & MM \\
\hline 1923 & Danimarka’da Halk İdadileri & İhsan (Sungu) & MM \\
\hline 1923 & Fransa'da Talim ve Tedris & Dr. Sabri & MM \\
\hline 1924 & Amerika Maarifi Hakkında Musahabe & Şefik Feyzi & MM \\
\hline 1924 & Amerika’da Terbiyenin Gayesi & Mustafa Rahmi & MM \\
\hline 1924 & Amerika'da Terbiye Vasıtası: Cehd ve İş & Mustafa Rahmi & MM \\
\hline 1924 & $\begin{array}{l}\text { Anglo Sakson Mektebinde Terbiye-i Bede- } \\
\text { niye ve Ahlakiye }\end{array}$ & Abdullah Cevdet & Süs \\
\hline 1925 & Bazı İtalyan Mektepleri Hakkında (rapor) & $\begin{array}{l}\text { İsmail Hakkı (Ton- } \\
\text { guç) }\end{array}$ & MVM \\
\hline 1925 & Avrupa Meslek Mekteplerine Dair (rapor) & $\begin{array}{l}\text { İsmail Hakkı (Ton- } \\
\text { guç) }\end{array}$ & MVM \\
\hline 1925 & $\begin{array}{l}\text { Bugünkü Almanya'da Mektep Teşkilatı } \\
\text { Nasıldır? }\end{array}$ & Arif Cemil & Meslek \\
\hline 1925 & $\begin{array}{l}\text { Almanya ve Fransa'da Lisan-1 Ecnebi Ted- } \\
\text { risat1 (tetkik) }\end{array}$ & Zeki Mesud (Alsan) & MVM \\
\hline 1925 & $\begin{array}{l}\text { Almanya'da Vatani Terbiye Meselesi (tet- } \\
\text { kik) }\end{array}$ & Zeki Mesud (Alsan) & MVM \\
\hline 1925 & Bulgaristan Maarifi (rapor) & Ahmet Hilmi(Yolaç) & MVM \\
\hline 1926 & $\begin{array}{l}\text { Anglo Sakson Mekteplerinde Din ve Ter- } \\
\text { biye }\end{array}$ & Abdullah Cevdet & Süs \\
\hline
\end{tabular}


1926 Anglo Sakson Mekteplerinde Terbiye

1926 İtalyan İlk Tedrisat Kanunu

1926 Mektepçiliğin Kâbesinde

1926 Rusya Maarifi Hakkında Rapor (rapor)

1926 Rusya Maarifi Hakkında (rapor)

1926 Fransa Orta Muallim Mektebi (rapor)

1926

1926

1926

1926

1926

1926

1926 Fransa'da Mesleki Tahsil ve Mesai

1926 Çek Slovakya'nın Muallim Birlikleri

1927 Rusya’da Bir Tecrübe Mektebi

1927 Moskova'da Radişcef Tek İş Mektebi

1927 Almanya'da Yardım Mektepleri Teşkîlatı

1927 Orman Mektebi-Açık Hava Mektebi

1927 Almanyada Mesleki Tahsil

1927 Danimarka Jimnastik Tarihçesi

1927 Çekoslovakya’da Skol Teşkilatı
Ermenistan'da Maarif Hareketleri ve İçtimai Teşkilat
Abdullah Cevdet

Süs

Muallimler

Birliği

Hıfzırrahman Raşit

(Öymen)

Amedi Mat.

Nafi Atuf (Kansu) /

Ridvan Nafiz (Edgüer)

Zekâi (Apaydın) MVM

Kemal Zaim (Sunel) MVM

İsmail Hakkı (Ton-

guç)

MVM

MVM

güzarlığı

MVM

MVM

Muallimler

Birliği

Muallimler

Birliği

Osman Burhaned- Diş Tabibleri din Cem. Mec.

Nurettin Ali MM

Ridvan Nafiz (Edgüer)

Terbiye

Ridvan Nafiz (Edgüer)

Terbiye

Hilmi

MVM

Ahmet Hilmi (Yolaç)

MVM

Ahmet Hilmi (Yolaç)

MVM

Vildan Âşir (Savaşır) / Nizamettin Rıfat (Kırşan)

Vildan Âşir (Savaşır) / Nizamettin Rıfat (Kırşan)

Mehmet Ragıp 
1927 Avusturya'da Yeni Program Hareketi

Hıfzırrahman Raşid

(Öymen)

MVM

1927

Yeni Programlardan - Rus Müfredat Prog- Hıfzırrahman Raşid ramları

(Öymen)

MVM

1927 Almanya ve Şark İlmi

Zeki Mesud (Alsan) Hayat

1927 Bulgaristan Maarif Teşkilatı

Ali Haydar (Taner)

MM

1927 Amerika'da İctimaiyât Tedrisatı

Mehmet İzzet

Darülfünûn

Ed. Fak. Mec.

1927

Rusya Şuralar İttihadı Sosyalist Cumhuriyetinde Maarif-i Umumiye

A. Âli

Fikirler

Rusya Şuralar İttihadı Sosyalist Cumhuri-

1927 yetinde Maarif-i Umumiye-Tedrisat-1 Meslekiye

1927 Rus Şuralar İttihadında Maarif - Harsi Siyaset Faaliyeti

1928 Almanya'da Maarif

1928 Amerika'da Terbiye Hareketleri

1928 Avusturya’da Maarif

1928 Almanya'da Maarif

A. Âli Fikirler
A. Âli
Fikirler

Mim. Rahmi Fikirler

Eyüp Hamdi (Akman)

Yeni Fikir

Mustafa Rahmi

(Balaban)

Fikirler

Mustafa Rahmi

(Balaban)

Fikirler

1928 Rusya Şuralar İttihadı Sosyalist Cumhuriyetinde Maarif - İlim
A. Âli
Fikirler

1930 Finlandiya’da Ev İdaresi Tedrisatı

Ali Haydar (Taner) Terbiye

1930 Avusturya’da Maarif İnkılabı

Ahmet Fuat (Baymur)

Terbiye

1930 Bugünkü Almanya

Selim Sırrı (Tarcan) Devlet Mat.

1931 Bulgaristan Maarifi

Ali Haydar (Taner) Devler Mat.

1931 Rusya'da Mektepten Evvelki Terbiye

Kâzım Nami (Duru) Terbiye

1933 İngiltere'de İlk, Orta ve Yüksek Tahsil

Orhan Recep

Yeni Türk

1933 Sovyetlerde Bayram ve Terbiye

Nusret Kemal

Ülkü

1934 Amerikan Pedagogları Bugünkü Mektepten Ne Bekliyor?

Bedriye Mustafa Yeni Adam

Amerika Terbiye'de İçtimai, İktisadi Hedefleri Değiştiriyor?

Bedriye Mustafa Yeni Adam 
1934 Almanya Maarifi

1934 Almanya Mektepleri

1934 Almanya'da Maarif

1934 Meksika’da Yeni Köycülük Programı

1934 Meksika’da Köycülük

1934 Fransa Maarif Teşkilatında Müfettişler

1935 Fransa’da Yüksek Ticaret Tahsili

1935 İngiltere'de Tahsil

1936 Fransa’da Kültür İşleri

1936

1937 Amerika Toplu Tedrisi

1937

1937

1938 Winnetka Sistemi
Amerika Birleşik Devletlerinde Okulculuk Sistemleri

Sovyet Rusya’da İlköğretim ve Eğitim İşleri (rapor)

Sovyet Rusya'da Yüksek Tahsil ve İlim Hayatı Hakkında Rapor

Bir Seyahatin Notları: Bulgaristan, Macaristan, Almanya: 1937-38
Reşat Şemsettin

(Sirer) / İsmail

Hakkı (Tonguç)

Münir Rașit

(Öymen)

Asım İsmet (Kültür)

Nusret Kemal

(Köymen)

Nusret Kemal

(Köymen)

Hasan Âli Yücel

Mustafa Nihat

Orhan Recep

Hasan Âli Yücel

Eren Bilge Niyazi

Kemal Kaya

Heyet

Hifzı Veldet

Hasip Ahmet

Aytuna

İsmail Hakkı Ton-

guç
Devlet Mat-

baas1

Resimli Şark

Kültür

Ülkü

Çankaya Mat.

Devlet Mat.

İkt. Tic. Mec.

Ülkü

Devlet Mat.

Gündüz San.

Fik. Mec.

Enerji

Kültür Bak.

Remzi Yay.

İnkilâp Kit.

Remzi Yay.

\section{Almanya Eğitim Sistemi Hakkında Hazırlanan Raporlar}

Ankara Erkek İlk Öğretmen Okulu El İşleri öğretmeni İsmail Hakkı (Tonguç)'nın, 1925 yılında meslek okulları hakkında incelemelerde bulunmak üzere gittiği Almanya’nın da içinde bulunduğu Avrupa ülkelerine gezisi sonucunda hazırladığı iki raporu Maarif Vekâleti Mecmuası'nda yayımlanmıştır. Avrupa Meslek Mekteplerine Dair başlıklı birinci raporunda, medeni ülkelerin bütün hükümet kurumlarının, milletin genel ve mesleki eğitimiyle ilgilendiklerini, bu raporun da meslek ve sanayi okullarına ait kısmını kapsadığını belirtmektedir (İsmail Hakkı 1925: 46). Raporda, Almanya ve İngiltere'deki meslek okulları ve mesleki eğitim hakkında bilgiler yer almaktadır. Almanya meslek okullarının tarihsel gelişimleri hakkında bilgiler verildik- 
ten sonra, bu okulların amacının, ilkokullarda okunan bilgileri geliştirmek ve takviye etmek olduğu; bu okulların ilk tahsil üzerine zorunlu bir tahsil devresini oluşturdukları belirtilmektedir. Bu okullara ilişkin yapılan yasal düzenlemelerle geçirdikleri dönüşüm; okutulan dersler ve okulların işleyiş̧i; kuruluş ve gelişiminde önemli çalışmaları olan kurum ve kişiler hakkında bilgiler verilmektedir. Ayrıca Münih Meslek Tamamlama Okulları ve Sanayi’i Okullarının çocuklara ve kızlara mahsus olmak üzere iki kısma ayrıldığ 1 belirtilerek, bu okul türlerinin kuruluşları, tarihsel süreçteki gelişimleri ve işleyişleri hakkında bilgiler yer almaktadır (İsmail Hakkı 1925: 47-54).

İsmail Hakkı (Tonguç)'nın ikinci raporu 1926 yılında Maarif Vekâleti Mecmuasinda "Avrupa Tecrübe Mektepleri Hakkında" başlığıyla yayımlanmıştır. Raporda, yeni okulların toplumun gereksinimlerini göz önüne alarak çocuğu eğitmek istedikleri belirtilerek Almanya, Paris, Londra Floransa gibi çeşitli bölgelerde incelenen okul türleri ve işleyişi hakkında ayrıntılı bilgiler sunulmaktadır. İlk olarak yeni okul ve eski okul uygulamalarındaki farklılıklar ortaya konulmaktadır: Yeni okulların sosyal kanunlardan oluştuğu; çocuğun ihtiyaç ve kabiliyetlerine önem verdiği; terbiye vasıtaları, izcilik, gençler birliği gibi içtimai teşkilatlarla çocuğun takviye edilerek gerçek hayatın içine atıldığı; çocukların çalışılarken bir kalıba girmek mecburiyetinde olmadıkları; ders esnasında çocukların herhangi bir ihtiyaçlarında başkalarını rahatsız etmemek koşuluyla serbestçe dolaşabildikleri; öğretmenin öğrenci karşısında bir amir olmadığı, yardımcı olduğu; oyun sayesinde çocuklara doğal yeteneklerini geliştirme firsatı verildiği; tecrübe okulları için sokak, pazar yeri, nehir, orman, tarla, fabrika gibi faaliyetin toplandığı yerlerin çok yararlanılacak eğitim araçları olduğu; fen, tarih, coğrafya, lisan, riyaziye, plastik gibi maharetlerin bu kaynaklardan toplandığı belirtilmektedir. Almanya'daki meslek okullarının anlatıldığı bölümlerde Güney Almanya'daki kır terbiye yurtları ve Leibzig Deneme Okulları, türleri (İş Okulu-Arbeitsschule, Öğrenme Okulu-Lernschule), tarihsel gelişimi ve işleyişi bu okul türlerinde bulunan şubeler hakkında bilgiler verilmektedir. Buna göre kır yurtlarının 9-18 yaşlarındaki çocuklara iyi düzenlenmiş bir toplum hayat1 yaşatmak, mümkün olduğu kadar iyi ve çağdaş eğitim verme arzusunda oldukları; burada yetişen gençlerin hayatlarını iyi ve kıymetli bir işe verebilmeleri gerektiği belirtilerek, kırda eğitim hakkında ilkeler, uygulamalar, dersler ve çizelgeler, yurtların tarihsel gelişimi ile Alman kır yurtlarının kurucusu, eğitimci Herman Lietz' in hayatı hakkında ayrıntılı bilgilere yer ve- 
rilmektedir. Leibzig Tecrübe (Deneme) Okulları ile ilgili bölümde ise, bu okulların iş okulu ilkesini temel aldıkları, bilgiyi beceriyle güçlendirdikleri, bilgiyi uygulamaya dönüştürdükleri, insanların gereksinimlerini kitaplardan değil doğadan öğrenmeleri için çocuğu doğanın içine bıraktıkları, iş derslerinin bütün derslerin temelini oluşturduğu, küçük sınıflarda çoğu dersin Toplu Öğretim biçiminde verildiği, bahçe işleri için okulun ihtiyacına yetecek kadar bir bahçesinin olduğu, beden eğitimi ve müzik derslerinden de yararlanıldığı belirtilmektedir (İsmail Hakkı 1926: 13-37).

Maarif Vekâleti İlk Tedrisat Umum Müdürü Reşat Şemsettin (Sirer) ve Maarif Vekâleti Mektep Müzesi Müdürü İsmail Hakkı (Tonguç)'nın, farklı tarihlerdeki Almanya incelemeleri, 1934'te Almanya Maarifi adıyla kitap olarak yayımlanmıştır. 350 sayfa ve 5 bölümden oluşan kitap istatistikler, şemalar ve fotoğraflarla zenginleştirilmiştir. Almanya'da ilköğretim kurumları (ilkokullar, halk okulları, şehir ve köy ilkokulları, yardım okulları, işitme ve görme engellilere özel okullar); mesleki eğitim kurumları (tamamlama, ihtisas, çiftlik, inşaat işçiliği, maden işçiliği, ormancılık, ticaret, bahçecilik, kadın işlerine mahsus, san'at, ziraat, makina, mensucat okulları, ortaokullar, üniversiteler ve işleyişi); eğitimle ilgili kanunlar, okulların tesisi ve idareleri (ilkokullar ve tâli okullarının-ortaöğretim- işleyişi ve idare edilmesi); öğretmen yetiştirme (ilkokullar, ortaokul, tâli okullara öğretmen yetiştirilmesi ve öğretmen akademileri); talim ve terbiyede ileri hareketlere (temayüller, siyasî partilerin eğitim programları, tecrübe okulları ve serbest terbiye mesaisi, halk eğitimi, pedagoji cemiyetleri ve pedagoji neşriyatı) ilişkin ayrıntılı bilgiler verilmektedir (Sirer ve Tonguç 1934: 1-350). Gündüzalp (1951: 113,114) bu kitabın, Almanya gibi ileri bir memlekette modern pedagojik görüşlere göre her derecedeki okulları ayrıntıll, tasnifli ve düzenli biçimde anlattığını, kitabı okuyanların büyük bir kültür milletinin okulculuk alanında elde etmiş olduğu büyük başarılarını ve nasıl bir evrim geçirmiş olduğunu iyi anlayacağını belirtmektedir.

İlköğretim Genel Müdürü İsmail Hakkı Tonguç, 1937-1938 ders yılının yaz tatili sonlarında Kültür (Milli Eğitim) Bakanlığı tarafından, başka ülkelerde ilköğretim, köy eğitimi, zorunlu iş hizmeti konularında inceleme yapmak üzere Bulgaristan, Macaristan, Almanyàya gönderilmiştir. Tonguç'un bu incelemeleri 1939 'da Canlandırlacak Köy adlı kitabında ek olarak verilmiştir. Kitap 266 sayfa ve 7 bölümden oluşmaktadır. Bu incelemeler Bulgaristan, 
Macaristan, Almanya eğitim sistemlerini ele almakta ve Bir Seyahatin Notları başlığı adı altında 73 sayfada anlatılmaktadır: Tonguç bu çalışmasıyla, ilköğretim alanında çalışanları ve köy eğitimi ile uğraşanları ilgilendirecek, köy işleri alanında zorunlu ve faydalı bulduğu yolları aydınlatmak istediğini belirtmektedir. Diğer bir deyişle Köy Enstitüleri'nin hazırlık aşamasında, Almanya incelemeleri köy eğitimine ilişkin bilgileri içermektedir. Almanyảnın anlatıldığı bölümde, şehir ve köy durumu genel hatlarıla anlatıldıktan sonra, köylerdeki çeşitli okul türleri tanıtılmıştır. Buna göre, köy ilkokulları, köy meslek okulları, ihtisas okulları, köy kadınları okullarına ilişkin bilgiler verilmektedir (Tonguç 1939: 193-233).

\section{Fransa Eğitim Sistemi Hakkında Hazırlanan Raporlar}

Maarif teşkilat ve müesseseleri hakkında incelemelerde bulunmak üzere, 1930 yılında, Bakanlık müfettişlerinden Hasan Âli (Yücel) Fransa’ya gönderilmiştir. Bir yıllık görevi süresince, Fransız kültürünün yayılması ve işlemesinin esaslarını araştırarak hazırladığı raporu 1931'de Bakanlığa sunmuştur. Yücel'in bu incelemeleri, 1934 'te Fransa Maarif Teşkilatında Müfettişler ve 1936 da Fransa'da Kültür İ̧̧leri başlığıyla kitap olarak yayımlanmıştır. Fransa Maarif Teşkilatında Müfettişler başlıklı kitap 23 sayfadan oluşmaktadır. Bu kitapta Fransa'daki müfettişlik bölümleri, görev ve yetkileri genel hatlarıyla anlatılmıştır. Buna göre Fransa'da müfettişlik, umumî müfettişler (ilk tedrisat, anaokulları, orta tedrisat ve teknik tedrisat umumî müfettişleri); akademi müfettişleri; ilk müfettişler (ilk tedrisat, anaokulları ve teknik tedrisat müfettişleri) olarak üç ana bölümden oluşmaktadır (Hasan Âli 1934: 1-23).

1936 'da yayımlanan Fransa'da Kültür İsleri başlıklı kitap, 1930 yılı incelemelerinin, bu süre içerisindeki değişiklikleri de dikkate alınarak ilaveleriyle oluşturulmuş halidir. 255 sayfadan oluşan ve Fransa Ulusal Eğitim Bakanlığı'nın ayrıntılı olarak anlatıldığı, Fransa Maarif Tarihi olarak da nitelendirilebilecek olan bu kitap 8 bölümden oluşmaktadır. Giriş bölümünde Fransa Ulusal Eğitim Bakanlığı’nın genel kuruluşu, merkezi örgütü, öğretim dereceleri, kurulları ve teftiş işleri anlatılmaktadır. Fransa’da yükseköğretimin tarihçesi, kurumları ve işleyişi; ortaöğretim tarihçesi, kurumları ve işleyişi; ilköğretim tarihçesi, kurumları, işleyişi, okul programları, öğretmen yetiştiren okulları; tekniköğretim tarihçesi, kurumları ve işleyişi; Güzel Sanatlar ve müzik öğretiminin tarihçesi, kurumları ve işleyişi; tarım öğretiminin tarihçesi, kurumları ve işleyişi; okul sonu öğretim (okul saatleri dışında kalan 
sürenin, çeşitli okul kademelerine ilişkin biçimde nasıl değerlendirildiği); 1933-1935 yıllarına ait Fransa Devleti’nin genel bütçesi, Kültür Bakanlığı bütçesi ve çeşitli okul kademelerine ilişkin istatistikler yer almaktadır (Yücel 1936: 1-255). Kitabın sonuna eklenen bibliyografya, grafikler ve fotoğraflar ile kitap, oldukça kapsayıcı ve bilgilendirici bir içeriğe sahip olmuştur.

\section{Avusturya Eğitim Sistemi Hakkında Hazırlanan Raporlar}

Hıfzırrahman Raşit (Öymen)'in Avusturya eğitimi ile ilgili incelemeleri 1927 yılında, "Avusturya'da Yeni Program Hareketi" başlığıyla Muallimler Mecmuasinda yayımlanmıştır. Ayrıca 1926'da ilk baskısı, 1928'de ise geliştirilmiş ikinci baskısı yapılan Mektepçiliğgin Kâbesinde adlı kitabında, Avusturya eğitim sistemi incelemeleri resimlerle, istatistiklerle ayrıntılı biçimde tanıtılmıştır. Bu çerçevede kitap yeni programlar ve toplu tedris, Rus programları, Avusturya programları, yeni müfredat programları, toplu tedriste öğretmenlik yetkileri ve sınıf öğretmenliği sistemi, toplu dersten ayrı gösterilen dersler, dini öğretim ve yeni programlar, Viyana okullarında renkli camlardan ve sinemadan istifade, Viyana okullarında aile birlikleri, zorunlu ilköğretim, kız-erkek karma öğretim, vatani malumat ve yurt bilgisi dersleri, edebi müsamere geceleri, geriler pedagojisi ve geriler okulu, Viyana Maarif Şûrası, öğretmen okulları, pedagoji enstitüleri, Viyana Pedagoji Enstitüsü ve ilkokul öğretmenlerinin hayatına ilişkin ayrıntılı bilgileri içermektedir (Hıfzırrahman Raşit 1928: 1-256).

İlköğretim Müfettişi Ahmet Fuat (Baymur), öğrenim gördüğü yıllardaki (1928-1931) incelemelerinde Avusturya'ya, özellikle Viyana okullarına, çeşitli ülkelerden çok sayıda insanın öğrenim için geldiğini belirtmektedir. Bu incelemeleri 1930-1931 yıllarında "Avusturya'da Maarif İnkılabı" başlığıyla Maarif Vekâleti'nce çıkarılan Terbiye Mecmuasinın 24, 25, 27, 29, 32, 33 ve 35. sayılarında 7 bölüm olarak yayımlamıştır. Ahmet Fuat ilk yazısında, Viyana’yı Mektepçiliğin Kâbesi yapan etmenlerin neler olduğunu tartışmıştır. Avusturya maarif inkılâbının, özelde Viyana’nın Mektep̧̧iliğin Kâbesi haline gelmesinin, iktisadî, siyasî ve terbiyevî üç unsurun etkisi altında gerçekleştiğini belirtmektedir (Ahmet Fuat 1930a: 34-36). İkinci yazısında Avusturya maarif inkılâbının gerçekleşmesindeki amaçların neler olduğu, yeniliklerin hangi prensipler etrafında yapıldığı anlatılmaktadır. Buna göre, Avusturya'da maarif inkılabının daha önceden düzenlenen bir program çerçevesinde gerçekleşmediği, tecrübe sonucunda ortaya çıkan yeni ihtiyaca göre yeni 
önlemlerin alındığı, maarif kanunlarının esasının 1869 'da düzenlenmesine karşın, ancak 1920'lerde çağdaş eğitim ve öğretimin hiçbir esaslı prensibinin ihmal edilmediği belirtilmektedir (Ahmet Fuat 1930b: 16-27). Üçüncü yazısında Avusturya’da maarif inkılabının tarihçesi, yıllara göre yapılan düzenlemeler, Otto Glöckel'in Eğitim Bakanı olmasıyla başlayan uygulamalara (federasyon terbiye müesseseleri, ilkokul reformu, okul teşkilatında tadilât, halk eğitimi, okullarda dinî etkinin azaltılması, Viyana Maarif Şûrası) yer verilmektedir (Ahmet Fuat 1930c: 34-42). Dördüncü yazısında Avusturya idarî teşkilâtı anlatıldıktan sonra maarif teşkilatı genel hatlarıyla anlatılmıştır (Ahmet Fuat 1930d: 27-35). Beşinci yazısında Avusturya maarif teşkilatındaki okullar genel hatlarıyla tanıtılmaktadır. Çocuk bahçeleri, zorunlu okullar, orta öğretim okulları, yüksekokullar, işleyişi, okula başlama yaşları, okul ve öğrenci sayılarına yer verilmektedir. Ahmet Fuat, Avusturyalıların okullardan bahsederken öncelikle çocuk bahçelerinden veya anaokullarından başlamadıklarını, bu kurumları, okul olarak kabul etmediklerini belirtmekte ve bu durumu, zihniyetler arasındaki farkın en güzel örneği olarak değerlendirmektedir (Ahmet Fuat 1931a: 5-19). Altıncı yazısında çocuk bahçeleri, vazifeleri, tarihçesi ve çocuk bahçelerindeki Fröbel ve Montessori uygulamaları ve prensipleri karşılaştırmalı olarak anlatılmaktadır (Ahmet Fuat 1931b: 35-42). Son yazısında, Viyana'daki çocuk bahçelerinin teşkilatlanması, işleyişi ve uygulamalarına, fotoğraflarla desteklenerek yer verilmiştir (Ahmet Fuat 1931c: 25-44).

\section{Bulgaristan Eğitim Sistemi Hakkında Hazırlanan Raporlar}

1925 yılında Bulgaristan maarifi hakkında incelemelerde bulunmak üzere görevlendirilen Bakanlık müfettişlerinden Ahmet Hilmi (Yolaç)'nin hazırladığı rapor, "Bulgaristan Maarifi” başlı̆̆ılla aynı yıl Maarif Vekâleti Mecmuasinda yayımlanmıştır. Raporda Bulgaristan İlk Mektepleri, anaokulları, ortaokulların -gimnazyumlar- işleyişi, erkek ve kız gimnazyumlarının haftalık ders programı çizelgeleri, meslek okulları, türleri ve işleyişi, Sofya'daki okullar, ziraat okulları, öğretmen okulları işleyişi ve haftalık ders dağıtım çizelgeleri, yabancı ve azınlık okullarının işleyişi ve uyruklara göre sayıları anlatılmaktadır. Bulgaristan'da yaşayan Türklerin yalnızca ilk ve ortaokul derecesinde okulları olduğunu, birçok Bulgar gimnazyum incelemesinde birkaç Türk öğrenciye rastlanıldığını; Türk okullarındaki öğretmenlerin ekseriyetle ilk ve ortaokul tahsili gördüklerini, fazla tahsil gören Türk öğ- 
retmen sayısının az olduğunu; öğretmenlerin öğretim ilke ve yöntemlerine vakıf olmadıklarını; Türklerin okullarının nüfuslarıyla uyumlu olmadığını; aralarında yüksek tahsil görmüş insanlara pek az rastlanıldığını belirtmektedir. Raporda ayrıca öksüz yurtları ve öğretmen derneklerinin işleyişi hakkında da bilgiler verilmiştir (Ahmet Hilmi 1925: 12-45).

Ali Haydar (Taner)'in 1931 yılında Maarif Vekâleti tarafından yayımlanan Bulgaristan Maarifi adlı kitabı 272 sayfa ve 14 bölümden oluşmaktadır. Kitapta ilk olarak Bulgar tarihi, Eğitim Bakanlığı teşkilatı ve okul türleri genel hatlarıyla anlatılmıştır. İlk 4 bölümde ilk, özel, orta, meslek mekteplerinin tarihçeleri ve teşkilatlanmaları ayrıntılı biçimde anlatılmıştır. 5-9. bölümlerde yükseköğretimin tarihi, teşkilatlanması, türleri ve işleyişi anlatılmıştır. Bu çerçevede Sofya Darülfünunu, Serbest Darülfünun, Güzel Sanatlar, Musiki, Bulgar Bilim Akademileri anlatılmıştır. 10-14. bölümlerde ise Bulgar Milli Tiyatrosu, Sofya’da Bulgar Milli Kütüphanesi, Halk Okuma Yurtları, Müzeler, Beden Terbiyesi ve 1929-1930 yılına ait devlet ve maarif bütçesi ayrıntılı olarak anlatılmıştır (Ali Haydar 1931:1-272). Gündüzalp (1951:41), kitabın basıldığı tarihten beri Bulgaristan Maarifi'nin çok değişmiş olmakla birlikte, bu konuda hâlâ yeni bir kitap bulunmadığı için bu kitabı ibretle okunmaya değer olarak bulmaktadır.

1937-1938 ders yılında İsmail Hakkı Tonguç'un Balkan ülkelerine yaptığı gezi (Bulgaristan, Macaristan, Almanya) incelemeleri, 1939'da Canlandirtlacak Köy adlı kitabın içinde "Bir Seyahatin Notları" başlığıyla ek olarak yayımlanmıştır. Tonguç, Bulgaristan gezisinde Sofya, Plevne, Tırnova, Eskipazar, Filibe, Pazarcık kentleri ile otuzdan fazla köy ve kültür kurumlarını görmüştür. Yazıda, Bulgaristan’n şehir ve köy nüfusuna ait bilgiler verildikten sonra Bulgaristan'ın eğitim durumu ortaya konulmuştur: Maarif sistemi ve teşkilatı, Maarif Nezareti, okul öncesi, ilköğretim, ortaöğretim, üniversite, halk eğitimi, zirai durum, zirai kooperatifler, ziraat öğretimi ve eğitimi, mecburi iş hizmeti teşkilatı ve işleyişi hakkında kısa bilgiler verilmektedir. Bulgaristan'da her okul türünün köylere kadar yayıldığı, köylülerin karakterini ve milli kültürünü kaybetmeden en modern formasyon müesseselerinde yetişebildiği belirtilmektedir (Tonguç 1939: 193-212). 


\section{Rusya Eğitim Sistemi Hakkında Hazırlanan Raporlar}

Maarif Müsteşarı Nafi Atuf (Kansu) ve Teftiş Heyeti Başkanı Rıdvan Nafiz (Edgüer)'in hazırladıkları rapor, "Rusya Maarifi Hakkında” Rapor başlığıyla 1926 yılında Maarif Vekâleti Mecmuasinda yayımlanmıstır. 44 sayfalık raporda; Rusya Sosyalist Şûralar Cumhuriyetleri İttihadı (SSCB) Teşkilatı Esasiye Kanunu’nda maarif işlerinin bütün cumhuriyetler için özerk olmasına, maarif teşkilatı, talimatname ve programlarda farklılığına karşın, terbiye faaliyetlerinde hâkim olan fikirlerin, prensiplerin, amaçların bir olduğu belirtilmektedir. Bu çerçevede SSCB Komiserliği'nin amaçlarının milli iktisadın sosyalist ilkelere göre gelişimi ve açığa çıkmasını temin etmek; şehirlerde ve köylerde üretim kabiliyetini ve kudretini arttırmak; halka komünizm esasına göre siyasi bir eğitim vermek; halkın milli medeniyetlerini umumi harsa esas teşkil edecek biçimde geliştirmek olduğu belirtilmektedir.

Raporu hazırlayanların Rusya ziyaretleri çoğunlukla tatil aylarına denk gelmiştir. Burada bütün dairelerin şefleriyle faaliyetleri ve düşünceleri hakkında bilgi almışlar; açık olan yatılı okullara giderek öğrencilerle ve öğretmenlerle görüşmüşler; köylere giderek köy evleri ve köylülerle ilgilenmişler, fabrikaları ve fabrika yanlarında açılan okulları incelemişlerdir. Rusya’dan sonra Birliğin en büyük Cumhuriyeti olan Ukrayna’da, Kiyev ve Odesa’da kısa süreli incelemelerde bulunmuşlardır. Bu iki Cumhuriyetteki incelemelerine göre yeni rejimin kalıcı olabilmesi ve devamı için en önemli vazifelerin yeni ilke ve fikirleri halka indirmek; halkın siyasi ve içtimai terbiyesini tamamlamak; yeni devlet şeklini imanla muhafaza ve müdafaa edecek bir nesil yetiştirmek için gereken bütün önlemleri almak; talim ve terbiye faaliyetlerini buna göre düzenlemek, maarif kurumlarını devletin amaçlarına göre yeniden oluşturmak ve işletmek olduğu belirtilmektedir. Bu görevler ve bunlarla ilişkili işlerin sorumluluğunun rapordaki özgün anlatıma göre, Maarif Halk Komiserliği'ne (Narkompros) verildiği ve bu teşkilatın birimlerinin Teşkilat ve İdare Dairesi, Devlet Şûra-yı İlmiyesi, İçtimai Terbiye Dairesi, Mesleki Tedrisat Dairesi, Siyasi Terbiye ve Mektep Harici Tedrisat Dairesi, Milli Ekaliyetler Dairesi, Ulum ve Sanayi-i Nefise Dairesi, Matbuat Dairesi, Devlet Bütçesine Dâhil Olmayan Müessesat Dairesi olarak 9 birimden oluştuğu belirtilmektedir. Raporda bu birimlerin görevleri ve işleyişinin yanı sıra teftiş işleri, vilayetlerde Maarif Teşkilatı ve Okul Teşkilatları (okuldan evvelki terbiye, okul tahsili, meslek okulları, teknikumlar- orta meslek okulları- amele fa- 
külteleri, amele kursları, yüksek meslek okulları, diğer çocuk müesseseleri, öğretmenlerin yetiştirilmesi-Pedagoji Enstitüsü, Pedaloji Enstitüsü) ayrıntılı olarak anlatılmaktadır. Bu raporda ayrıca Rusya Maarif Komiserliği Teşkilatı'nın şemasına da yer verilmiştir (Akt. Kansu ve Kansu 2011: 409-450; Nafi Atuf ve Ridvan Nafiz 1926: 1-44).

Rıdvan Nafiz (Edgüer)'in Rusya seyahatinin ürünü olan ve 1927 yılında Terbiye dergisinde yayımlanan "Rusyàda Bir Tecrübe Mektebi" başlıklı yazısı, rapor başlığı taşımamakla birlikte aslında "Rusya Maarifi Hakkında Rapor"a ek bir rapor niteliğindedir. Buna göre, Tecrübe okullarının kuruluş gayelerinin muhtelif terbiye temayüllerini tecrübe etmek ve programları bu doğrultuda hazırlamak, yeni ders programlarının eğitim ve öğretim esaslarının uygulanmasında diğer okullara örnekler oluşturmak olduğu; bu okullara güzide öğretmenler ve eğiticilerin tayin edildiği; okulun içinde öğrencilerin tarlada, ormanda, ve okul binalarında çalıştıkları; öğrencinin kendi işini kendisinin görmesine son derece önem verildiği; okul öğretmenlerinin bir zorunluluk olmadığı sürece öğrenci işlerine müdahalede bulunmadığı; okulun iç işlerinin öğrenci ve öğretmenlerin eşit haklara sahip göründükleri bir topluluk hayatı olduğu; öğretmen ve öğrenciler arasında bir arkadaş topluluğu tesis edildiği; Rusya’nın diğer okulları gibi karma olduğu; 8 yaşından 18 yaşına kadar kız ve erkek öğrencinin bir arada ders gördükleri; atölyelerde çalışıkları; tedrisat planının Dalton esasları doğrultusunda yönetildiği; terbiye ve inzibatta ise geniş bir şekilde kendini idare (self government) esaslarının uygulandığı belirtilmektedir. Raporda, bu okulların işleyişlerini gösteren yaz ve kış aylarına ait zaman çizelgesi ile öğrencilerin ve öğretmenlerin faaliyetlerine ait fotoğraflar da bulunmaktadır (Rıdvan Nafiz 1927a: 17-22).

Rıdvan Nafiz (Edgüer)'in 1927 yılında Terbiye dergisinde yayımlanan "Moskovàda Radişcef Tek İş Mektebi” başlıklı yazısı da, ek rapor niteliğindeki ikinci raporudur. Bu rapor, 5 sayfa metin ve 4 sayfa tablo olmak üzere toplam 9 sayfadan oluşmaktadır. Buna göre, bu okulların programının devlet bilim şurası tarafından hazırlanmasına karşın, okullar için belirlenen amaçlara sadık kalmak koşuluyla planlarını serbestçe hazırlayabildikleri ve programların Orta Rusyảnın şartlarına göre hazırlandığı belirtilmektedir. Ayrıca okul süreleri, programda yer alan dersler ve uygulanması, tedris usulleri, Dalton Planının uygulanması, bu okullardaki eğitim ve öğretimin amaçları, okulun işleyişi ve kurulları, atölyeleri ve öğretim ilkelerine yer verilmiştir. 
Bununla birlikte bu okullardaki kâğıt işleri, karton işleri, marangozluk işleri ve maden işlerine dair programları gösteren tablolara yer verilmiştir (Rıdvan Nafiz 1927b: 122-130).

1933 yılında Cumhuriyetin 10. yılı kutlamalarına katılmak üzere Türkiye’ye gelen Sovyetler Birliği Maarif Komiseri Bubnof, 1936 yllında, her öğretim derecesinden seçilecek 40 kişilik öğretmenler heyetini Sovyet Rusya’ya misafir olarak, incelemelerde bulunmak üzere davet etmiştir. 5-28 Eylül 1936 tarihinde, Rüştü Uzel'in başkanlığında, ilkokul, ortaokul, lise ve enstitü öğretmenleri ile üniversiteden dört doçentten oluşan heyet Rusya’ya gitmiştir (Velidedeoğlu 1977: 214-245). Bu incelemeler "Sovyet Rusya'da İlköğretim ve Eğitim İşleri” başlığıyla 1937 yılında Kültür Bakanlı̆̆ı Dergisinnde yayımlanmıştır. Ayrıca Heyette olan her bir eğitimci bu incelemelerini ayrı ayrı raporlaştırmışlardır. Örneğin, "Sovyet Rusya'da Yüksek Tahsil ve İlim Hayatı Hakkında Rapor” başlıklı inceleme bu seyahate katılan Velidedeoğlu tarafından hazırlanmışır (Taşdemirci 2001: 1).

“Sovyet Rusya'da İlköğretim ve Eğitim İşleri” başlıklı rapor 9 bölümden oluşmakta ve raporda Rusyadaki ilköğretim kademesi ayrıntılı olarak anlatılmaktadır. Birinci bölümde ilkokul öncesi terbiye teşkilatı (çocuk bakımevleri, yeni doğmuş çocuklar koğuşu, çocuk yuvaları); ikinci bölümde halk eğitimi, teşkilatlanması ve işleyişi; üçüncü bölümde zorunlu eğitim yaşındaki çocukların öğretim ve eğitim müesseseleri, maarif idaresi; okulların haftalık ders programları ve işleyişi; dördüncü bölümde ilkokul kitapları, çocuk yayınları ve çocuk müesseseleri, halk neşriyatı; beşinci bölümde köy okulları teşkilatı, köy öğretmenleri, köyde ümmilikle mücadele ve halk terbiyesi; altıncı bölümde ilköğretimde teftiş işleri; yedinci bölümde tecrübe okulları ve faaliyetleri; sekizinci bölümde ilkokul öğretmenleri; dokuzuncu bölümde ise öğretmen yetiştirme yolları anlatılmaktadır (Kültür Bakanlı̆gr Dergisi 1937: 198-241).

\section{Sonuç ve Tartışma}

Yeni kurulan Cumhuriyet'in modernleşme projesini hayata geçirmede en ekili aracı eğitim sisteminin geliştirilmesi olmuştur. Cumhuriyet, eğitim sistemi aracılığıyla siyasi meşruiyetini sağlamlaştırabileceği gibi ihtiyaç duyduğu yurttaşları da yetiştirebilecekti. Bunu gerçekleştirmenin yolu ise çağdaş eğitim düşüncesinden ve deneyiminden yararlanılmasıdır. Kuşkusuz bu durum, dış politikada takip edilen yurtta barı̧s dünyada barış ilkesinin ve 
Cumhuriyet' in dünyayla bütünleşme, yenilikleri yakından izleme, kendisi için gerekli ve yararlı olanı alma isteğinin sonucudur. Üstelik inceleme yapılan ülkenin siyasal rejiminin nasıl olduğuna bakılmaksızın, o ülkenin eğitim sistemine dair incelemelerin yapılması Cumhuriyet' in pragmatist yönünün göstergelerinden biri olarak değerlendirilebilir. Yurt dışına öğrenci gönderilmesi, yurt dışından uzmanlar çağrılması, yurt dışına araştırma ve inceleme için uzmanlar gönderilmesi ve tercüme faaliyetleri olanaklar dâhilinde sürdürülen bu sürecin temel taşları arasındadır. Çağdaş ülkelerdeki eğitim düşüncesini ve uygulamalarını yerinde görmenin, bu işin mimarlarıyla diyalog içinde sorunları ve çözüm önerilerini tartışmanın en etkili yolu ise çeşitli ülkelerin eğitim sistemlerini inceleme için uzmanların gönderilmesi olmuştur.

Bu çalışmada Atatürk döneminde Almanya, Fransa, Avusturya, Bulgaristan ve Rusya eğitim sistemi ve uygulamaları hakkında yayımlanan 15 rapor incelenmiştir. Bu çerçevede araştırmada, yurt dışına gönderilen uzmanlar tarafından Almanya hakkında hazırlanan 2 rapor ve 2 kitap, Fransa hakkında hazırlanan 2 kitap, Avusturya hakkında hazırlanan 1 kitap ve rapor, Bulgaristan hakkında hazırlanan 2 kitap ve 1 rapor, Rusya hakkında hazırlanan 4 rapor olmak üzere toplam 7 kitap ve 8 rapor incelenmiştir.

1925-1926 yıllarında Hıfzırrahman Raşit Öymen, 1928-1931 yılları arasında Fuat Baymur tarafindan incelenen Viyana Yüksek Pedagoji Enstitüsü ve eğitim uygulamalarının Türkiye'de ilkokul ve öğretmen yetiştirme programlarını etkilediği söylenebilir. Türkiye’nin 1926 İlkokul Programı, Viyana Temel Eğitim Programının ilk beş yıllık bölümünden esinlenmiştir (Altunya 2006: 48). 1926 yılında Nafi Atuf Kansu ve Ridvan Nafiz Edgüer'in, 1936 'da bir heyetin Sovyet eğitim sistemi ile ilgili incelemeleri üretici eğitim, kimsesiz ve yoksul çocukların eğitimi, öğretmen yetiştirme ve eğitim örgütlerini geliştirme açılarından yararlı olmuştur. Ayrıca 1930'da Hasan Ali Yücel'in Fransa, 1931'de Ali Haydar Taner'in Bulgaristan, 1934 'te Tonguç ve Reşat Şemsettin Sirer'in Almanya, 1937'de Tonguç'un Balkan ülkeleri incelemeleri öğretmen yetiştirme, köyde eğitim ve eğitim örgütlerini geliştirme gibi konularda yararlı olmuştur (Altunya 2005: 24, Gündüzalp 1951: 194). Bununla birlikte bu raporlarda bahsedilen, farklı sınıf düzeylerinden öğrencilerin aynı derslikte, etkin bir halde öğrenim görmelerine dayanan Dalton Planinın, günümüzde varlı̆̆ı devam eden birleştirilmiş sınıflarda örnek alınarak uygulandığı söylenebilir. 
İsmail Hakkı (Tonguç) 1925'te Almanya, Fransa, İngiltere ve İtalya ülkelerinden oluşan Avrupa ülkeleri incelemesinden sonra 1926'da, Mustafa Necati döneminde, Maarif Vekâleti Levazım ve Alatı Dersiye Müzesi Müdürlügü̈ne (Mektep Müzesi Müdürlüğü) atanmıştır (Tonguç 2009: 77). Bu Müdürlüğün amac1, eğitim teknolojileri yönünden öğretimi çağdaşlaştırmak ve iş eğitimini okullara sokmak ve yaygınlaştırmaktı. Bunun yanı sıra, ilkokullarda her türlü ders araç gerecinin bulunduğu mektep müzelerinin açılması, orta öğretim ve öğretmen okulları için ders araç-gereci standartlarını belirleme, kimi okullar için gerekli ders araç-gereçlerinin tümünü bulundurma, bazılarında ise bölgesel kullanım biçiminde hizmet verme, ders araç-gereçleri için rehber kitapçıkların hazırlanması, okul müzesinde kurulan gezici öğretmen kitaplığından öğretmenlerin parasız olarak yararlanması, iki aylığına posta ile öğretmenlere kitap gönderme, öğretmenlere resim-elişleri kursları gibi önemli yenilikler de bu müdürlüğün yaptığı işler arasındadır. Mektep Müzesi'nin açtı̆̆ $\dot{I}_{\xi}$ İlkelerine Dayanan Eğitim Kursları (1926-1928)'nda ders vermek üzere, Almanya'da İsmail Hakkı'nın hocalı̆̆ını yapmış olan Leibzig Pedagoji Enstitüsü ve İş Öğretmen Okulu profesörlerinden Frey ve Stiehler getirtilmiş, çevirmenliğini ise Tonguç'un kendisi yapmıştır (Tonguç 2009: 78-80). Ayrıca 1927 yılında köy ilkokulları için ayrı bir öğretim programı yapılmış, 3. Sınıf programı arasına yurt bilgisi dersi konulmuş, resim-elişleri dersleri köy okullarının koşullarına uygun olarak hazırlanmış ve köy kızları için ev işleri dersi eklenmiştir. Tonguç tarafından hazırlanan iş dersi programı ile Gazi Orta Muallim Mektebi'nin tüm bölümlerine her yıl için haftada birer saat iş dersi konulmuştu. 1932'de yurt dışında eğitimlerini tamamlayıp dönen beş resim-elişleri öğretmeniyle birlikte Tonguç, Gazi Eğitim Enstitüsü Resim Şubesi'ni kurmuş ve 1935 yılında 11 yıl sürecek olan İlköğretim Genel Müdürlüğü görevine getirilmiştir (Tonguç 2009: 89-168). Gündüzalp (1984: 313)'e göre Tonguç’un eserlerinde Alman eğitimcilerinden İsviçreli Pestalozzi ve Alman Kerschensteiner'in etkileri görülmektedir. Bu çerçevede Köy Enstitülerinin de mimarı olan Tonguç'un eğitim düzenlemeleri ve uygulamalarında, kendi teori ve pratiğini oluştururken incelenen ülkelerdeki örneklerden yararlandığı söylenebilir.

Tonguç’un Mektep Müzesi Müdürlügü döneminde, 1930 yılında Talim ve Terbiye Heyeti Başkanı Emin (Erişirgil)'in başkanlığında çeşitli ülkelerde, özellikle Rusya’da olduğu gibi okuma örgütü kurulması ve bir bayilik şirketi 
oluşturulması, bir okuma seferberliği açılması, köy postalarının düzenlenmesi, posta ücretlerinin indirilmesi ve kitaplarda indirim yapılması gibi kararlarının alınması (Bayır 1971: 70-72), Rusya hakkında hazırlanan raporlardan ve Tonguç่un raporlarından yararlanıldığının en açık kanıtı olarak kabul edilebilir.

Atatürk döneminde çeşitli ülkelerin eğitim işlerini inceleme için gönderilen uzmanlar, Maarif Vekâleti' nin taşra ve merkez teşkilatlarında öğretmenlikten en üst düzeye kadar eğitimle ilgili çeşitli görevlerde, kurullarda yer almışlar ve dönemin eğitim politikalarının belirlenmesinde etkin olmuşlardır. Kuşkusuz çeşitli ülkelerin eğitim sistemlerini inceleme için gönderilen uzmanların inceleme ve araştırma yapılan ülkelere ilişkin raporlarının, Türkiye'de eğitim bilimlerinin kuramsal gelişimi ve kurumsallaşmasında; eğitimin çağdaşlaşması sürecinde, eğitim alanındaki bina yapımından, araç-gereç kullanımına, eğitimle ilgili yasal ve yönetsel düzenlemelerden öğretim programlarına, çeşitli okul türlerine öğrenci seçiminden personel yetiştirilmesine, köyde eğitim ve Köy Enstitüleri'nin kurulmasına, iş ve sanat eğitimine kadar birçok öğenin çağdaş standartlara göre düzenlenmesinde ve uygulanmasında önemli katkıları olduğu söylenebilir. Ayrıca bu raporların ve eğitime ilişkin yeni düzenlemelerin, uygulamaların, gelişmelerin ve çeşitli yabancı eğitim düşünürlerinin görüşlerinin Maarif Vekâleti Mecmuasìnda yayımlanmasıyla, derginin ülkenin her tarafındaki okullara gönderildiği düşünüldüğünde, öğretmenler için, eğitim-öğretim teori ve pratiklerini geliştirebilecekleri, dünya ve ülke gündemini yakından takip etmelerinde karşılaştırmalı kılavuz niteliğinde bir işlevi olduğu söylenebilir. Bunların yanı sıra çeşitli ülkelerin eğitim işleri hakkındaki hazırlanan inceleme raporlarından hangisinden daha fazla yararlanıldığı sorusunun yanıtı, yurt dışından davet edilen yabancı uzmanlardan hangisinin raporundan daha fazla yararlanıldığ1 sorusunun yanıtıyla aynıdır. Diğer bir deyişle, 1939 yılında Maarif Vekilliği'nin kültür reformu çerçevesinde seri biçiminde yayımladığı Türk ve yabancı uzman raporlarının önsözünde belirttiği gibi bu raporlardan Maarif Vekilliği yardımcı materyal olarak yararlanmıştır. Dolayısıyla Maarif Vekâleti için, farklı tarihlerde ve farklı konularda yabancı uzmanların ve Türk uzmanların hazırladıkları raporların eğitim işlerinin düzenlenmesinde yol gösterici bir nitelikte olduğu; ancak tek bir kaynak olarak kullanılmayıp çeşitli ülkelerin uygulamaları ve Türk eğitim düşünürlerinin düşünceleri de değerlendirilerek, kendisi için yararlı olanı çeşitli komisyonlarda görüştüğü, 
uygulamalar sonucu tecrübe ettiği ve bu raporları, eğitim sisteminin düzenlemesinde karşılaştırmalı kaynak olarak kullandığı söylenebilir.

\section{Açıklamalar}

1 Milli güzideler, Cumhuriyet'in yetiştirmek istediği insan için dönemin alan yazınında sıkça vurgulanan bir ifadedir. Bununla anlatılmak istenen Cumhuriyet' in değerler dünyasını benimsemiş, bilgiyi bir süs olarak değil, günlük hayata uygulayabilen, sorgulayan bireylerden oluşan bir nesil yetiştirilmesinin ve aydın bir sınıfın oluşturulmasının istenmesidir. V. İcra Vekilleri Heyeti'nin 05.09.1923 tarihli programında maarifin terbiyevi vazifeleri, çocukların ve halkın terbiye ve talimi ile milli güzidelerin yetişmesi olarak gösterilmiştir. Milli güzidelerin yetiştirilmesinin ise Avrupa'daki irfan mekteplerine gönderilerek gerçekleştirileceği belirtilmiştir. Bkz. T.B.M.M. Zabit Ceridesi (1961). C. 1-2. Ankara: TBMM Matbaası.

2 Avusturyànın Viyana kenti, dönemin eğitim alanında 'Mektepçiliğin Kâbesi’ olarak kabul edilmektedir. 1920'lerde çağdaş eğitim ve öğretimin tüm ilkelerinin hayata geçirilmesiyle, Viyana şehrinin Mektepçiliğin Kâbesi durumuna geldiği ve kabul edildiği; bu çerçevede, dünyanın çeşitli ülkelerinden eğitimcilerin bu kente eğitim ve araştırma için akın ettiği söylenebilir. Ayrıntılı bilgi için bkz. Hıfzırrahman Raşit (1928). Mektepçiliğin Kâbesinde. İstanbul: Amedi Matbaasi; Ahmet Fuat (1930). "Avusturya’da Maarif İnk1labı". Terbiye 24-35:16-45.

\section{Kaynaklar}

Akyüz, Yahya (1987). "Hıfzırrahman Raşit Öymen". Cumburiyet Dönemi Eğitimcileri. Ankara: UNESCO Yay. 387-400.

Altunya, Niyazi (2005). Köy Enstitüsü Sistemine Toplu Bir Bakı̧. Ankara: Kelebek Matbaası.

Altunya, Niyazi (2006). Gazi Ĕ̈itim Enstitüsü, Gazi Orta Öğretmen Okulu ve Eğitim Enstitüsü. Ankara: Gazi Üniversitesi Yay.

Altunya, Niyazi (2015). “Türkiye’de Eğitim Bilimleri Öğretimi”. Eğitim Felsefesi Ulusal Sempozyumu. Ankara: Ankara Üniversitesi Basımevi. 288-300.

[Antel], Sadrettin Celal (1926). "Maarif Teşkilatı Hakkında Bir Layiha”. Maarif Vekâleti Mecmuası 7: 135-246.

Aslan, Cengiz (2014). Erken Cumburiyet Döneminnde Eğitim Bilimleri Alanında Yurt Dışına Öğrenci Gönderilmesi Olgusu (1923-1940). Doktora Tezi. Ankara: Ankara Üniversitesi.

Bayır, Ferit Oğuz (1971). Köyün Gücü. Ankara: Ulusal Basımevi.

[Baymur], Ahmet Fuat (1930a). "Avusturyảda Maarif İnkılabı". Terbiye 5 (24): 34-36 
[Baymur], Ahmet Fuat (1930b). "Avusturyàda Maarif İnkılabı". Terbiye 5 (25): 16-27. [Baymur], Ahmet Fuat (1930c). "Avusturyàda Maarif İnkılabı”. Terbiye 6 (27): 34-42. [Baymur], Ahmet Fuat (1930d). "Avusturyảda Maarif İnkılabı”. Terbiye 6 (29): 27-35. [Baymur], Ahmet Fuat (1931a). "Avusturyadda Maarif İnkılabı". Terbiye 7 (32): 5-19. [Baymur], Ahmet Fuat (1931b). "Avusturyàda Maarif İnkılabı”. Terbiye 7 (33): 35-42. [Baymur], Ahmet Fuat (1931c). "Avusturyaada Maarif İnkılabı”. Terbiye 7 (35): 25-44. Dewey, John (1939). Türkiye Maarifi Hakkında Rapor. İstanbul: Devlet Basımevi. [Edgüer], Rudvan Nafiz (1927a). "Rusya'da Bir Tecrübe Mektebi". Terbiye 1 (1): $17-22$.

[Edgüer], Rıdvan Nafiz (1927b). "Moskova’da Radişcef Tek İş Mektebi”. Terbiye 1 (2): 122-130.

Fraenkel, Jack R. et al. (2012). How To Design And Evaluate Research In Education. London: McGraw-Hill Higher Education.

Gündüzalp, Fuat (1951). Ögretmen Meslek Kitapları. C. I. Ankara: MEB Yay. Gündüzalp, Fuat (1955). Ögretmen Meslek Kitapları. C. III. Ankara: MEB Yay.

Gündüzalp, Fuat (1961). Öğretmen Meslek Kitapları. C. IV. Ankara: Milli Eğitim Basımevi.

Gündüzalp, Fuat (1984). Öğretmen Meslek Kitapları. C.V. Ankara: MEB Yay.

Gündüzalp, Fuat (2010). Ögretmen Meslek Kitaplar Kilavuzu (1840-1928). C.VI. Ankara: Çağdaş Eğitim Yay.

[Kansu], Nafi Atuf ve Rıdvan Nafiz [Edgüer] (1926). "Rusya Maarifi Hakkında Rapor”. Maarif Vekâleti Mecmuası 2 (9): 1-44.

Kansu, Metin Atuf ve K. Işık Kansu (2011). Cumburiyet Eğitim Devriminin Mülkiyeli Mimarı Nafi Atuf Kansu (1890-1949) Yaşamı ve Yazıları. Ankara: Mülkiyeliler Birliği Yay.

Kaya, Yahya Kemal (1987). "İsmail Hakkı Tonguç". Cumburiyet Dönemi Eğitimcileri. Ankara: UNESCO Yay. s.513-520.

Kurtça, Halis (1987). "Fuat Baymur". Cumburiyet Dönemi Eğitimcileri. Ankara: UNESCO Yay. 125-144.

Kültür Bakanlığı (1937). "Sovyet Rusya’da İlköğretim ve Eğitim İşleri”. Kültür Bakanlığı Dergisi 20 (1): 198-241.

Maarif Vekâleti (1927). "Maarif Vekili Mustafa Necati Beyefendi'nin Avrupa Tedkik Seyahati”. Maarif Vekâleti Mecmuası 11: 120-129.

Maarif Vekilliği (1941). Türkiye Cumburiyeti Maarif 1940-1941. İstanbul: Maarif Matbaası.

Milli Eğitim Bakanlı̆̆ı (1977). Cumburiyet Devrinde Milli Eğitim Bakanlı̆̆ı Teftiş Kurulu. İstanbul: Milli Eğitim Basımevi.

Milli Eğitim Bakanlı̆ğ Talim ve Terbiye Kurulu Kararları (1923-1940). 
Oğuzkan, Ferhan (1987). "Hasan Âli Yücel”. Cumburiyet Dönemi Eğitimcileri. Ankara: UNESCO Yay. 623-639.

[Öymen], Hıfzırrahman Raşit (1928). Mektep̧̧iliğin Kâbesinde. İstanbul: Amedi Matbaasi.

Özalp, Reşat ve Aydoğan Ataünal (1977). Türk Milli Eğitim Sisteminde Düzenleme Teşkilatı. İstanbul: Milli Eğitim Basımevi.

Özalp, Reşat (1987). "Rüştü Uzel”. Cumhuriyet Dönemi Eğitimcileri. Ankara: UNESCO Yay. 577-593.

Sirer, Reşat Şemsettin ve İsmail Hakkı Tonguç (1934). Almanya Maarifi. İstanbul: Devlet Matbaası.

Sorguç, Bahir (1982). 1920'den 1981'e Milli Eğitim Bakanlığı. İstanbul: Milli Eğitim Basımevi.

Sorguç, Bahir (1987). "Saffet Arıkan”. Cumburiyet Dönemi Eğitimcileri. Ankara: UNESCO Yay. 37-54.

[Taner], Ali Haydar (1931). Bulgaristan Maarifi. İstanbul: Devlet Matbaası.

Taşdemirci, Ersoy (2001). “1936 Yılında Sovyet Rusya’da Yüksek Öğretim Hakkında Hazırlanmış Bir Rapor ve Bu Raporun Türkiye'de Öğretmen

Yetiştirme Tarihi Bakımından Önemi”. Erciyes Üniversitesi Sosyal Bilimler Enstitüsü Dergisi 1 (11): 1-37.

TBMM Zabıt Ceridesi (1961). C. 1-2. Ankara: TBMM Matbaası.

[Tonguç], İsmail Hakkı (1925). "Avrupa Meslek Mekteplerine Dair". Maarif Vekâleti Mecmuası 1 (5): 46-72.

[Tonguç], İsmail Hakkı (1926). "Avrupa Tecrübe Mektepleri". Maarif Vekâleti Mecmuası 2 (6): 13-47.

Tonguç, İsmail Hakkı (1939). Canlandrrlacak Köy. İstanbul: Remzi Kitabevi. Tonguç, Engin (2009). Bir Eğitim Devrimcisi İsmail Hakkı Tonguç Yaşamı, Öğretisi, Eylemi. İzmir: Yeni Kuşak Köy Enstitülüler Derneği Yay.

Velidedeoğlu, Hıfzı Veldet (1977). Anıların İzinde. İstanbul: Remzi Kitabevi. [Yolaç], Ahmet Hilmi (1925). "Bulgaristan Maarifi". Maarif Vekâleti Mecmuası 1 (5): $12-45$.

[Yücel], Hasan Âli (1934). Fransa Maarif Teşkilatında Müfettişler. İstanbul: Devlet Matbaası.

Yücel, Hasan Âli (1936). Fransa'da Kültür İşleri. İstanbul: Devlet Matbaası. 


\title{
Reports of Turkish Experts about the Education Systems of Foreign Countries in the Period of Atatürk ${ }^{*}$
}

\author{
Cengiz Aslan $^{* *}$
}

\begin{abstract}
In the history of Turkish education, not only the reports made by foreign experts about Turkey, but also the reports made by Turkish experts about the education systems of foreign countries are important sources. In Atatürk's period, a great number of experts were sent abroad to study the education systems of different countries. Their reports were highly effective in regulating Turkish education system and decisions. In this study, within the scope of acquired documents and information, experts who were sent abroad to study the education systems of different countries in the period of Atatürk have been determined and their reports about the education systems of foreign countries have been studied. In this context, the reports about the education of Germany, France, Austria, Bulgaria and Russia have been initially examined.
\end{abstract}

\section{Keywords}

Turkish experts, reports, Germany, France, Austria, Bulgaria, Russia.

" Date of Arrival: 27 April 2016 - Date of Acceptance: 18 December 2019

You can refer to this article as follows:

Aslan, Cengiz (2021). "Atatürk Döneminde Türk Uzmanların Yabancı Ülkelerin Eğitim Sistemleri

Hakkında Hazırladıkları Raporlar”. bilig - Journal of Social Sciences of the Turkic World 96: 283-310.

** Dr., Ankara University, Faculty of Educational Sciences, Department of Educational Sciences - Ankara/ Turkey

ORCID ID: 0000-0003-3710-9838

cngzaslan@gmail.com 


\title{
Отчеты турецких экспертов периода Ататюрка о системе образования в зарубежных странах
}

\author{
Дженгиз Аслан ${ }^{* *}$
}

\begin{abstract}
Аннотация
В истории турецкого образования важными источниками являются не только отчеты зарубежных экспертов о Турции, но и отчеты турецких экспертов о системах образования зарубежных стран. В период Ататюрка большое количество экспертов было отправлено за границу для изучения систем образования разных стран. Их рапорты были очень эффективны в регулировании турецкой системы образования и решений. В этом исследовании в рамках полученных документов и информации были выявлены эксперты, которые были отправлены за границу для изучения систем образования разных стран в период Ататюрка, и изучены их отчеты о системах образования зарубежных стран. В этом контексте изначально рассматривались отчеты об образовании Германии, Франции, Австрии, Болгарии и России.
\end{abstract}

\section{Ключевые слова}

Турецкие эксперты, отчеты, Германия, Франция, Австрия, Болгария, Россия.

\footnotetext{
* Поступило в редакцию: 27 апреля 2016 г. - Принято в редакцию: 18 декабря 2019 г. Ссылка на статью:

Aslan, Cengiz (2021). “Atatürk Döneminde Türk Uzmanların Yabancı Ülkelerin Eğitim Sistemleri Hakkında Hazırladıkları Raporlar”. bilig - Журнал Гуманитарных Наук Тюркского Мира 96: 283-310.

** Д-р, Анкарский университет, Педагогический факультет, кафедра педагогики - Анкара/Турция ORCID ID: 0000-0003-3710-9838

cngzaslan@gmail.com
} 